\title{
RETRACTED ARTICLE: The role of temperature on the global spread of COVID-19 and urgent solutions
}

\author{
I. $\operatorname{Roy}^{1}$ (D)
}

Received: 22 June 2020 / Revised: 6 October 2020 / Accepted: 19 October 2020 / Published online: 19 November 2020

(c) The Author(s) 2020

The Editor-in-Chief has retracted this article. After publication, concerns were raised regarding the data analysis and proposed solutions. Independent post-publication peer review has concluded that the statistical analysis used to support the conclusions is not appropriate and the recommendations presented are not supported by the data and may not be safe. In order to protect public health the content has been removed. The author does not agree with this retraction.
Open Access This article is licensed under a Creative Commons Attribution 4.0 International License, which permits use, sharing, adaptation, distribution and reproduction in any medium or format, as long as you give appropriate credit to the original author(s) and the source, provide a link to the Creative Commons licence, and indicate if changes were made. The images or other third party material in this article are included in the article's Creative Commons licence, unless indicated otherwise in a credit line to the material. If material is not included in the article's Creative Commons licence and your intended use is not permitted by statutory regulation or exceeds the permitted use, you will need to obtain permission directly from the copyright holder. To view a copy of this licence, visit http://creativecommons.org/licenses/by/4.0/.

Editorial responsibility: Samareh Mirkia.

\author{
I. Roy \\ indrani.roy@ucl.ac.uk \\ 1 University College London (UCL), IRDR, London, UK
}

